\title{
Neolithic and Chalcolithic stone tools used in ceramics production: Examples from the south of Romania
}

\author{
Otis Crandell ${ }^{1}$, Corina Ionescu ${ }^{1,2}$, Pavel Mirea ${ }^{3}$ \\ 1. Babeș-Bolyai University, Geology Department, Cluj-Napoca, Romania. Email: \\ Crandell: otis.crandell@gmail.com; Ionescu: corina.ionescu@ubbcluj.ro \\ 2. Archeotechnologies \& Archeological Material Sciences Laboratory, Institute of International Relations, \\ History and Oriental Studies, Kazan (Volga Region) Federal University, Tatarstan, Russia. \\ 3. Muzeul Judetean Teleorman, str. 1848, nr.1, 140033, Alexandria, jud. Teleorman, Romania. \\ Email: pavelcmirea@yahoo.com
}

\begin{abstract}
:
This paper focuses on Neolithic and Chalcolithic stone tools found at the Măgura 'Buduiasca' and Vităneşti 'Măgurice' sites in southern Romania, which might been involved in the chaîne opératoire of ceramic pottery production. To better understand how ceramic objects were made during this period, it is important to know what tools were available. Representative artefacts were selected from the sites and have here been grouped based on their possible involvement in various stages of pottery production: a) quarrying of the raw claystone (picks); b) processing the raw materials (mortars and pestles); and c) surface finishing (smoothers, burnishers, polishers). The surface of the tools was examined by non-destructive methods (handheld loupe, stereomicroscope) with the aim of further determining their function and whether they were likely used in the ceramics industry.

This study provides examples of specific Neolithic and Chalcolithic stone tool types and illustrates characteristics useful for identifying their use. It also shows the possible chaîne opératoire of pottery produced during the Neolithic and Chalcolithic in the area of southern Romania.

It is considered that most of these tools categories, and likely most of the individual tools themselves, had multiple uses, or similar uses with different materials in different industries. It is therefore difficult to determine with much certainty whether they were only used within the ceramics industry.
\end{abstract}

Keywords: ceramics; stone tools; Neolithic; Chalcolithic; Lower Danube; Romania

\section{Introduction}

The production of ceramic pottery involves numerous steps, each of which requires different tools. Many studies focus on pottery, sometimes as tools from a functional point of view, sometimes as cultural markers used to date sites, and sometimes from the point of view of the raw material of which they are composed. The steps involved in pottery production are often studied based on the remains of the pottery itself with only minor mention of the tools used in its production.

Published by the School of History, Classics and Archaeology, University of Edinburgh ISSN: 2055-0472. URL: http://journals.ed.ac.uk/lithicstudies/

This work is licensed under a Creative Commons Attribution 2.5 UK: Scotland License. 
In the pottery chaîne opératoire, the pre-firing technological stages are important in obtaining good quality ware. The processing of the raw geological materials, i.e. clays and temper, necessitates specialised tools, some suitable for extraction from the pit, some for reducing the size of boulders resulting from excavation, and others for mixing. The final modelled object can be subject of surface treatment (e.g., smoothing, burnishing, and polishing) and decoration, all steps requiring special tools.

This paper presents an overview of tools with potential use in the production of ceramics during the Neolithic and Chalcolithic found at sites in Teleorman county (Lower Danube region, southern Romania) (Figure 1). Besides the stone tools, fragments of ceramic ware have been also found (Andreescu et al. 2009a; Andreescu et al. 2009b). A local production was assumed for the pottery, based mainly on the richness of sherds but no kilns have been found which were contemporary with the artefacts. Nevertheless, the wide range of stone tools, some highly specialized, found associated with pottery sherds arose the question if there is any connection between these tools and the pottery.

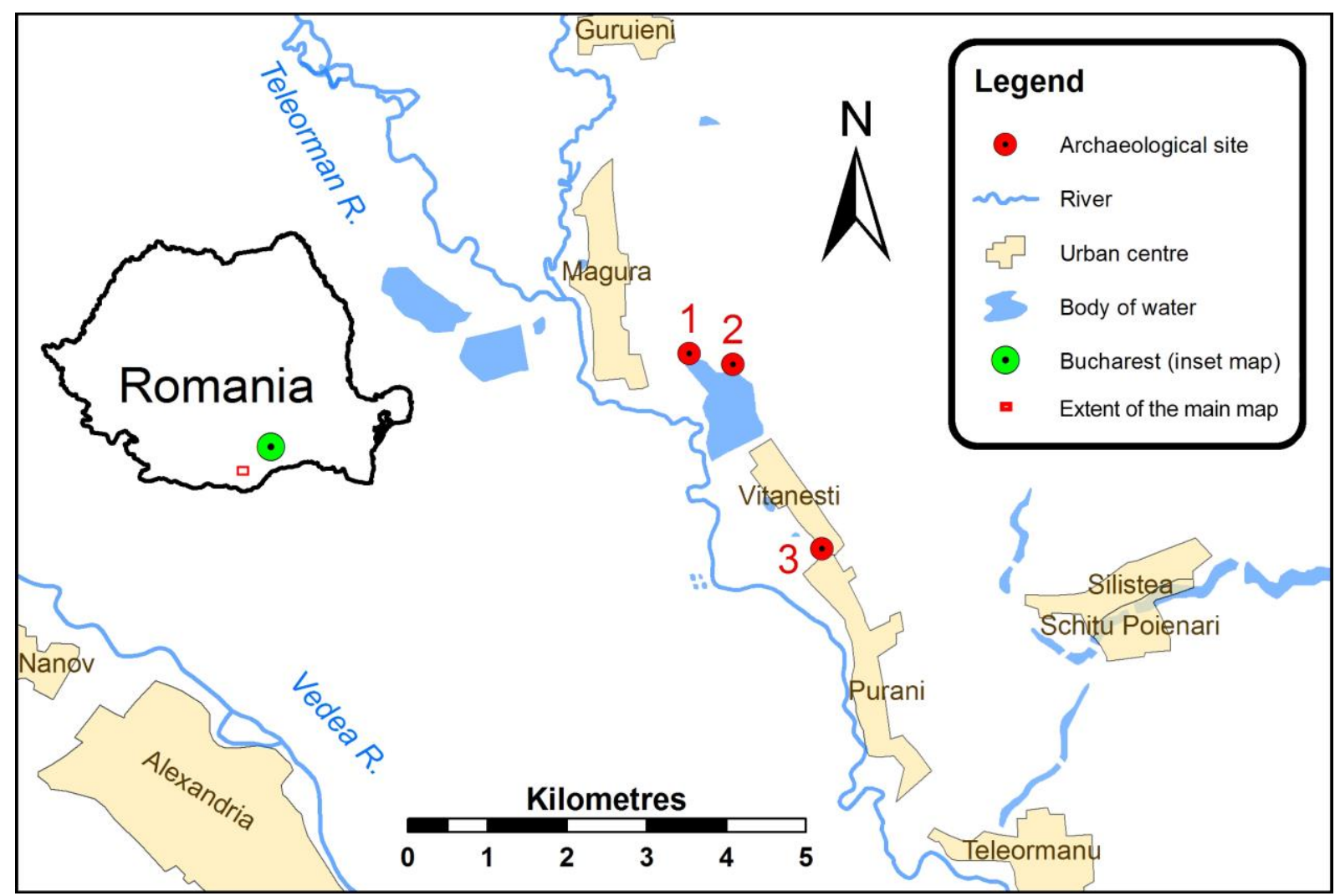

Figure 1. Location of the archaeological sites: 1. \& 2. Măgura 'Buduiasca', 2. 'Boldul lui Moș Ivănuș' component; 3. Vităneşti 'Măgurice'. The inset map of Romania shows the location of the map.

The shape and the surface characteristics of the lithic tools were analysed by optical nondestructive studies (with hand loupe and stereo microscope) in order to determine their function and usage traces, respectively. These characteristics might support a possible use in certain stages of the chaîne opératoire of pottery production.

\section{Archaeological context}

In the southern part of Romania, along the Teleorman River (Figure 1), a number of prehistoric sites have been extensively excavated and numerous ceramic and lithic artefacts have been uncovered (Mirea 2005a; b). Surface surveys were conducted by F. Florea in 1980, and by P. Mirea and Şt. Nedelcuţă-Apope in 2001. Subsequently, test excavations were 
carried out from 2001 to 2005 by R. Andreescu, D. Bailey and colleagues within the framework of the 'Southern Romania Archaeological Project' (Andreescu \& Bailey 2005).

Among the investigated sites are Măgura 'Buduiasca' (including its 'Boldul lui Moş Ivănuş' component) and Vităneşti 'Măgurice' (Figure 1), located near to each other and stratigraphically covering an almost complete time span from the Early Neolithic to the Late Chalcolithic (Table 1) (Andreescu 2006; Andreescu et al. 2008b; Mirea 2009). The artefacts from this study include polishers, smoothers, mortars, grinders, and possible mattocks or hatchets from the Neolithic and Chalcolithic contexts. Presently the artefacts found here are housed at the Teleorman County Museum in Alexandria.

Table 1. Sites from Teleorman County indicating the cultures present at each (marked with an ' $x$ '). Note that none of the sites had Boian occupations. Ages according to (Andreescu 2006; Andreescu et al. 2008b; Mirea 2009).

\begin{tabular}{|c|c|c|c|c|c|c|c|c|}
\hline \multirow{3}{*}{$\begin{array}{l}\text { Period } \\
\text { Sites }\end{array}$} & \multirow{3}{*}{$\begin{array}{l}\text { Culture } \\
\text { Phase }\end{array}$} & \multicolumn{3}{|c|}{$\begin{array}{c}\text { Early } \\
\text { Neolithic }\end{array}$} & \multicolumn{2}{|c|}{$\begin{array}{l}\text { Middle / Late } \\
\text { Neolithic }\end{array}$} & \multirow{3}{*}{$\begin{array}{l}\text { Late Neolithic } \\
\text { / Chalcolithic } \\
\text { Boian }\end{array}$} & \multirow{3}{*}{$\begin{array}{c}\text { Early } \\
\text { Chalcolithic } \\
\text { Gumelniţa }\end{array}$} \\
\hline & & \multicolumn{3}{|c|}{ Starčevo-Criş } & \multirow[t]{2}{*}{ Dudeşti } & \multirow[t]{2}{*}{ Vădastra } & & \\
\hline & & $\mathbf{I}$ & II & III & & & & \\
\hline $\begin{array}{l}\text { Măgura 'Buduiasca' } \\
\text { 'Boldul lui Moş Ive }\end{array}$ & $\begin{array}{l}\text { including } \\
\text { inuş') }\end{array}$ & $x$ & & $x$ & $x$ & $x$ & & \\
\hline Vităneşti 'Măgurice' & & & & & & & & $x$ \\
\hline
\end{tabular}

The Neolithic field settlement at Măgura 'Buduiasca' is located on the lower eastern terrace of the Teleorman River (about 300 m northeast of the current course of the river), about $1 \mathrm{~km} \mathrm{SE}$ of the village of Măgura and $7 \mathrm{~km} \mathrm{NE}$ of the town of Alexandria (Figures 1 and 2). 'Boldul lui Moş Ivănuş' is a protrusion of a secondary terrace, located about $500 \mathrm{~m}$ ESE of the rest of Măgura 'Buduiasca', registered by the 'Southern Romania Archaeological Project' as a sector of the latter. Together they may also be referred to as 'Buduiasca-Boldul lui Moş Ivănuş'. Note that although some earlier reports and articles treat them as separate sites, they are currently considered to be a single site.

The majority of the cultural remains found at Măgura 'Buduiasca' belong to the Late Neolithic Dudeşti culture, and include pit and surface houses, stone and bone tools, ceramic pottery, and anthropomorphic and zoomorphic sculptures. In addition to the Dudeşti materials, ceramics attributed to the Starčevo-Criş culture (phase III) and Vădastra culture (phase I) were also found, as well as possibly imported ceramics from the Karanovo IIIVeselinovo Neolithic cultures. Various flint tools have been discovered at this site, in the Vădastra context (Andreescu \& Bailey 2002; 2004; 2005; 2006; Andreescu et al. 2003; Andreescu et al. 2001; Crandell 2013; Mirea 2005a; b; 2009).

The settlement at 'Boldul lui Moş Ivănuş' is attributed to the Early Neolithic (StarčevoCriş) as well as the Late Neolithic (Dudeşti and Vădastra cultures) (Table 1). There are also sporadic remains from later periods not covered in this study. Similar to the rest of the Măgura 'Buduiasca' site, a long sequence throughout the Neolithic has been documented here (Andreescu et al. 2007; Andreescu et al. 2009b; Andreescu et al. 2008a). There were many early Neolithic complexes found in this component of the site. Among the very early ones were several surface dwellings and pits. The artefacts were comprised largely of household waste. A few whole pots were found. The ceramics from the Late Neolithic contexts belong to the early phases of the Dudeşti culture (Andreescu et al. 2007; Andreescu et al. 2009b; Andreescu et al. 2008a).

Vităneşti 'Măgurice' is a tell settlement located about $7 \mathrm{~km}$ northeast of Alexandria (Figures 1 and 3). The tell is $40 \times 45 \mathrm{~m}$ wide and $6.5 \mathrm{~m}$ high and is in a relatively good state of preservation. This site has been researched from 1993 until present (Andreescu 2006; 
Andreescu et al. 2009a; Andreescu et al. 2008b). The discoveries at this site are important as all three phases of the Gumelniţa culture (A1, A2 and B1) are present in the stratigraphy. The entire Gumelniţa B1 level, the last occupation layer, was uncovered, continuing the research with level A2. Surveys were also carried out to establish the stratigraphy of the settlement. The features at this site include surface dwellings, hearths and pits. Many artefacts have been discovered through excavations here. The artefacts are made from clay, flint and other rocks, bone, antler, copper and gold (Andreescu \& Borțun 1995; Andreescu et al. 1996; Andreescu et al. 2009a; Andreescu et al. 2008b; Mărgărit et al. 2014).

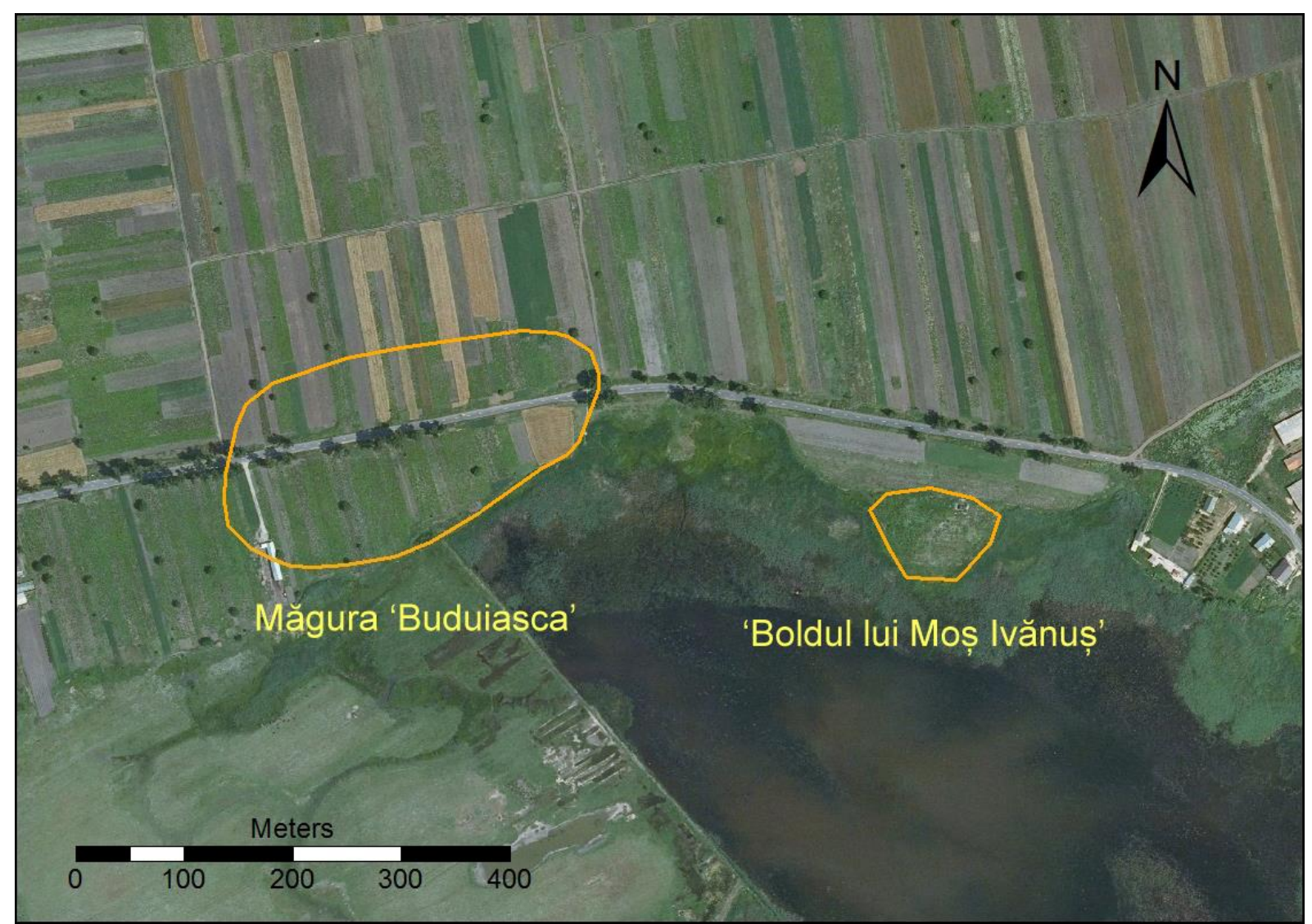

Figure 2. Aerial photograph showing the location of the the Măgura 'Buduiasca' site and the 'Boldul lui Moş Ivănuş' component. (Aerial photo from the ANCPI orthophoto dataset.)

\section{Tool typology}

The tools studied have here been grouped based on their possible usage in various stages of pottery production. We start with those which may have been used to quarry the raw clay, such as picks. We also describe tools such as mortars and pestles involved in processing the raw materials - particular by coarse and fine grinding. Finally, we come to surface finishing tools.

\section{Picks, mattocks, or hatchets}

The earliest stage in the production of ceramics is the extraction of clay from the ground. For this purpose the prehistoric populations used various tools, such as picks, hammers, axes, diggers (Rosenberg \& Gopher 2010; Wright 1992). Picks and hoes are used to extract of clay from the ground. They are often made of ground magmatic rocks or knapped chert. (See Figure 4 for examples.) Most of these type tools found at the study sites were fragmented. 
Due to the type of damage, along or originating from the leading edge, it is likely that they were damaged during use (Mirea 2005b).

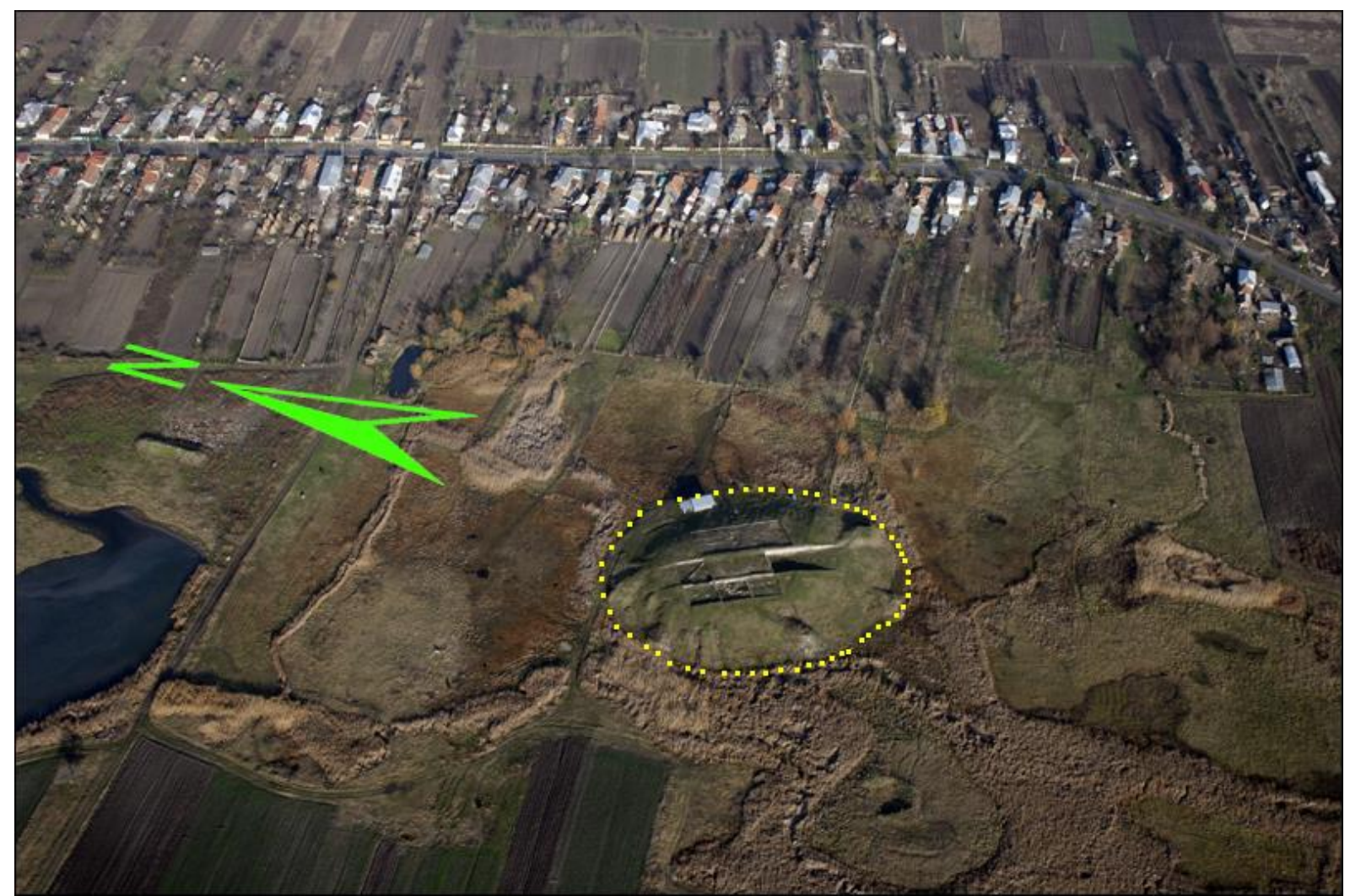

Figure 3. Aerial view of Vităneşti 'Măgurice' tell settlement. Photo from Andreescu (2011). (The site, outlined in yellow, is approximately $100 \mathrm{~m}$ wide.)
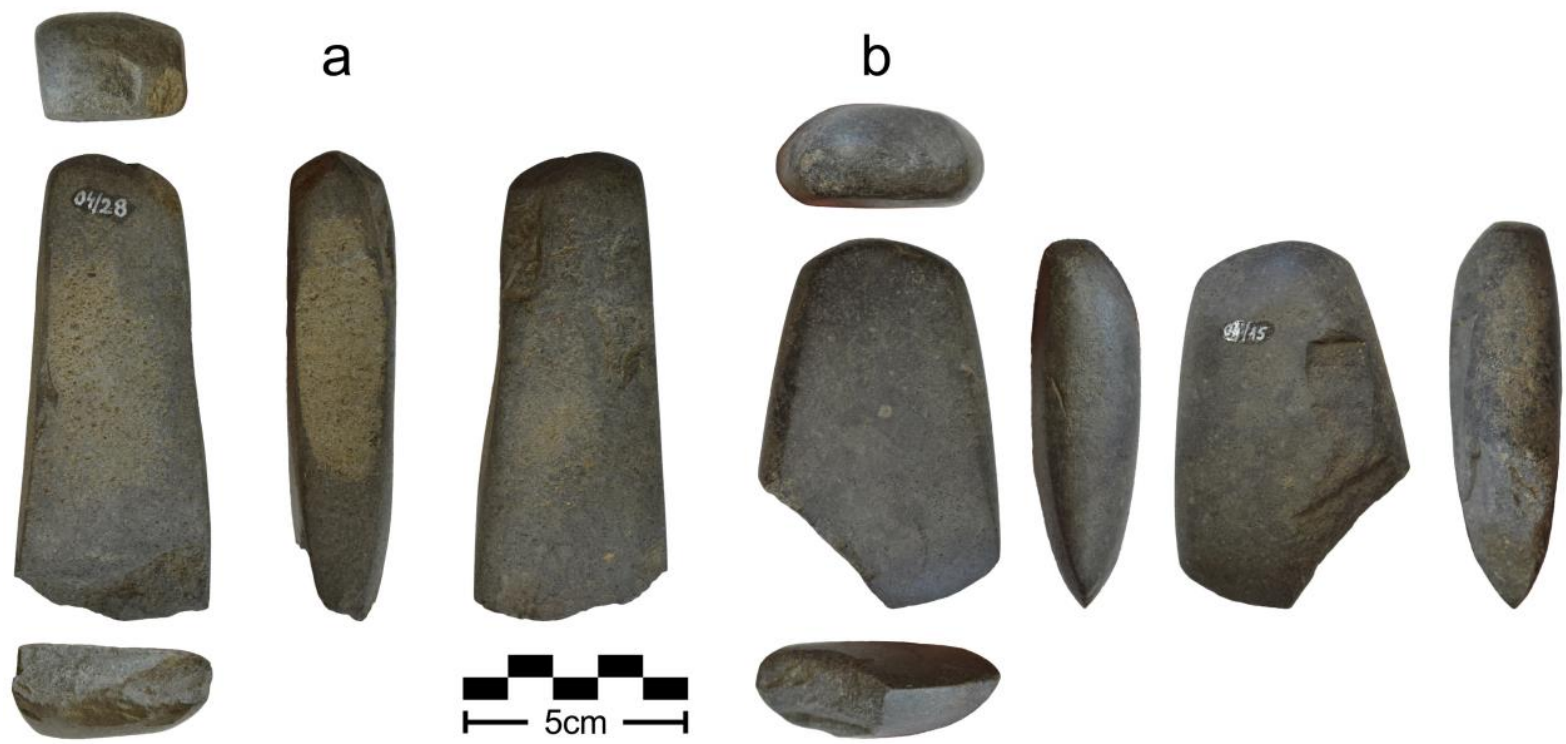

Figure 4. Examples of possible pick axe and chisel tools from Măgura 'Buduiasca'.

\section{Grinding slabs and handstones}

Wright (1992), Hamon (2008b) and (Bassetti \& Zamboni 1997) have outlined systems of classifying grinding and polishing tools based on function and form. Simplified versions of these classification systems will be used here. Wright (1992) defines grinding slabs (also 
known as grinding stones or querns) as is the lower of two grinding tools. The grinding action takes place on a relatively flat plain or indented, near flat surface. As the name implies, these tools are involved primarily in grinding material and much less so in pounding it (compare this with the use of mortars described below.) Whereas grinding slabs are passive tools, handstones (also known as grinding stones or grinders) are the accompanying active tools for grinding materials on grinding slabs. They generally have a large grinding surface which may vary in how flat or convex it is (Wright 1992). They must be easily gripped in a person's hand and be easily wielded. They will show grinding marks on one or more faces. Both grinding stones are commonly found at sites around the world and are mentioned by various authors (for example, Kozlowski 1989; Özkaya 2009; Rosenberg \& Gopher 2010; Simmons \& Rollefson 1984; Wayessa 2011; Wright 1992; Zurro et al. 2005).

The artefacts looked at this study were often made of quartzite or sandstone (see examples in Figures 5 to 7). Although the primary purpose of most would likely have been for grinding cereals, they were likely also used to grind various other materials, including temper (sand, gravel, potsherds) or even coarse fragments of pigment ores.
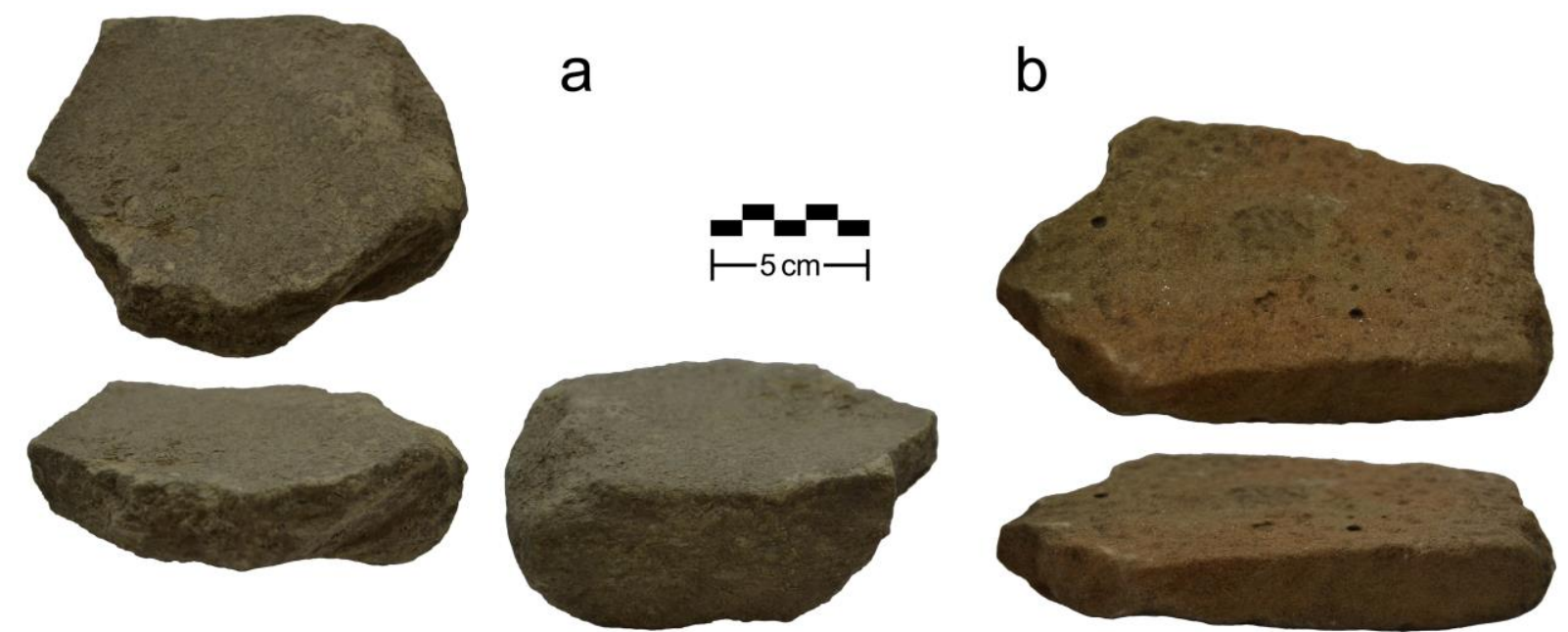

Figure 5. Examples of possible grinding slabs from Măgura 'Buduiasca'.

\section{Mortars and pestles}

Wright (1992) describes mortars as the lower of two tools used for pounding and vertical rotary grinding. By necessity these tools have a deeper and more circular indent than grinding slabs and may be more bowl-like in appearance. Like grinding slabs, mortars are passive tools. Pestles are the active tools which accompany mortars. They may be used to crush (through striking or a rocking motion) or grind (through circular movement) a material in a mortar. These tend to be thinner (relative to their length) than grinding handstones and have a more rod-like appearance. Wear will be limited to one or both of the ends of the pestle. As pestles are used also for pounding, they may have flake scars near the striking faces. Also due to pounding, the working faces may have more peck marks than a grinding handstone. There may also be deeper and more circular indent than grinding slabs and may be more bowl-like in appearance. The faces themselves vary from flat to slightly convex or well rounded. Flat faces may have bevelled edges. Wear can often occur along the sides near the working faces due to materials being ground on the vertical inner sides of the mortar. These tools are also common at Neolithic sites from other regions such as the Near East (see for example, Mithen et al. 2005; Nadel \& Rosenberg 2010; Özkaya 2009; Rosenberg \& Gopher 2010; Wayessa 2011; Wright 1992; Wright 1994). 


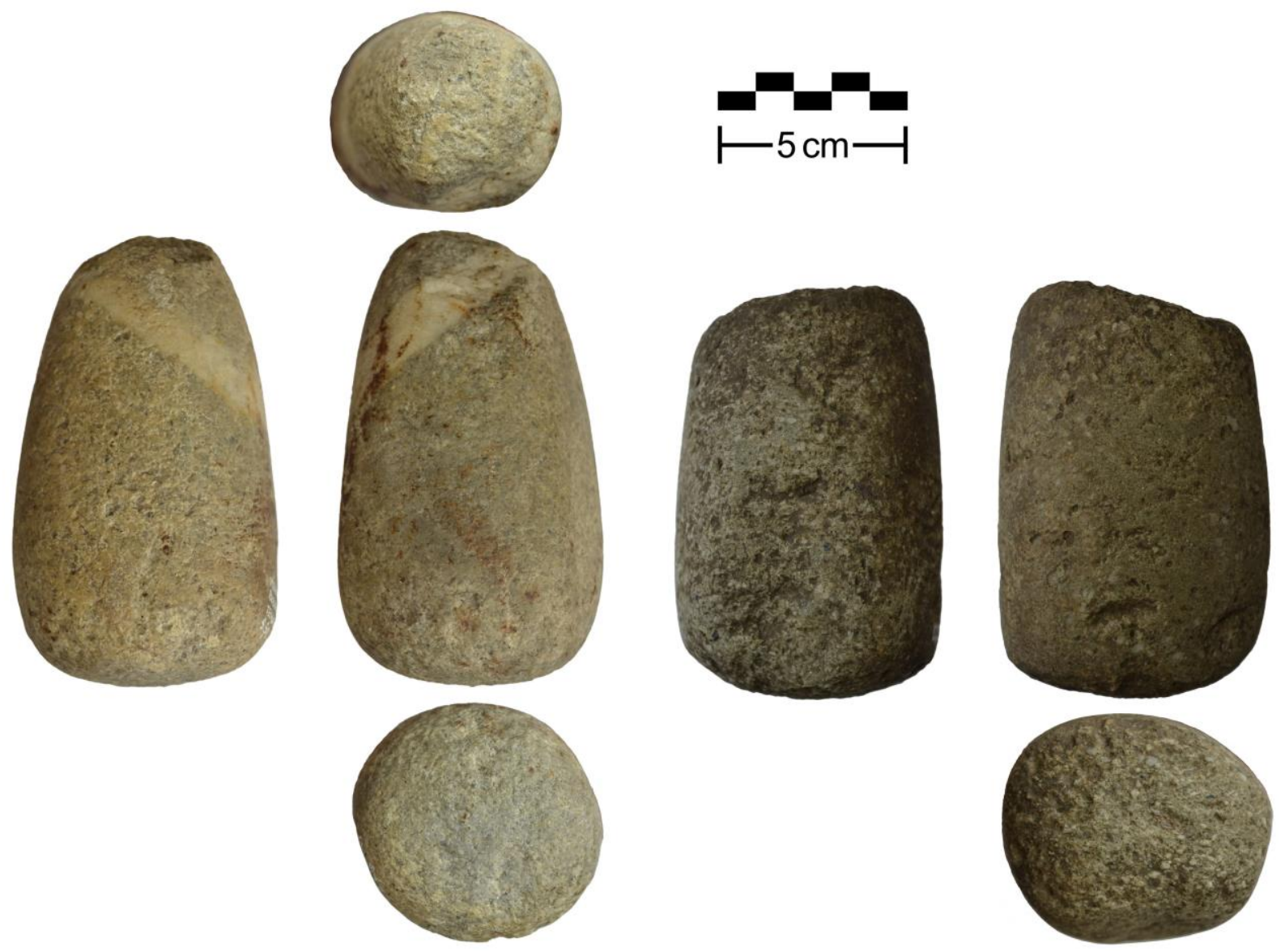

Figure 6. Examples of possible grinding hand stones from Măgura 'Buduiasca'. Grinding and crushing marks are visible on the lower surface.

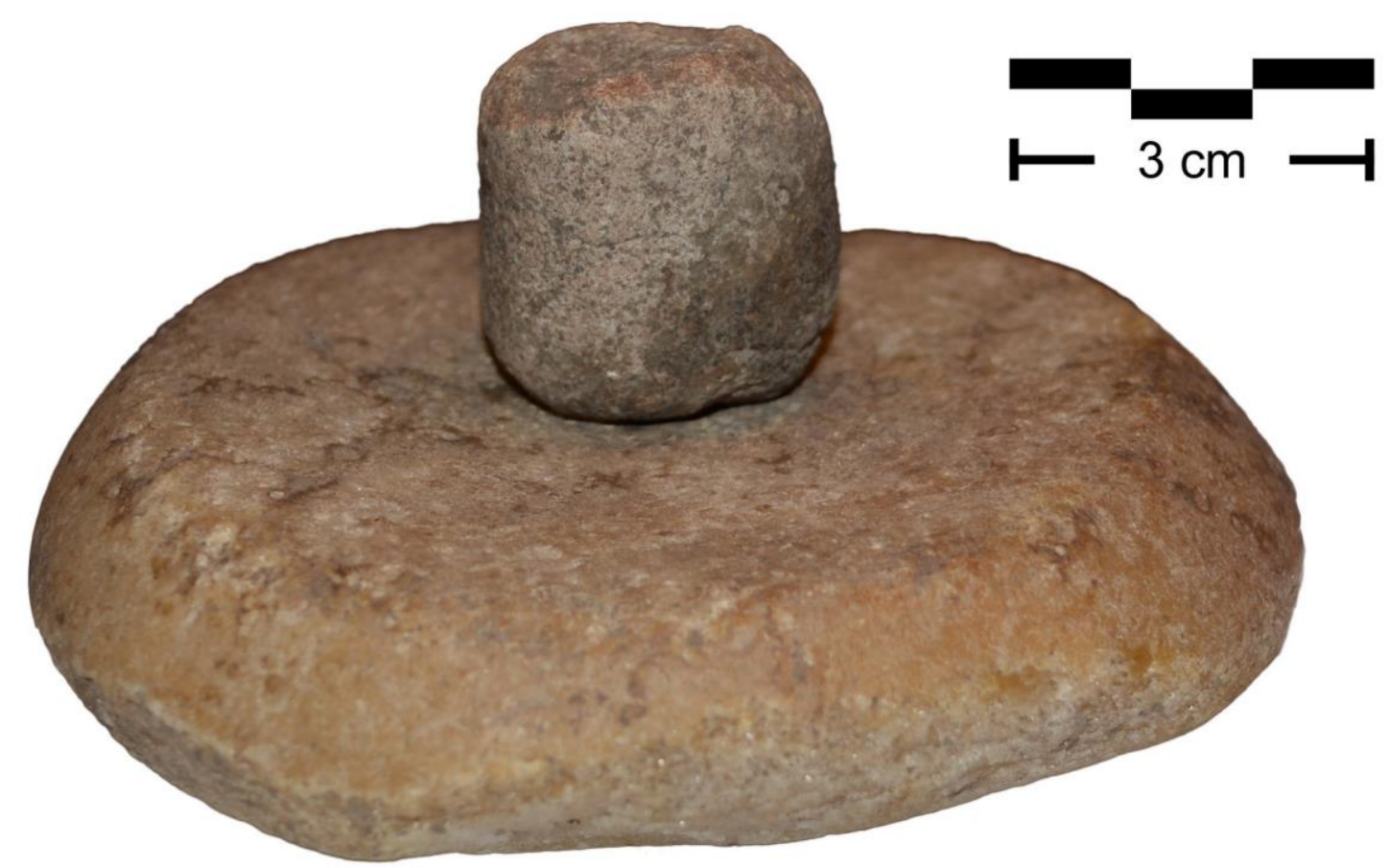

Figure 7. Example of a handstone on a grinding slab from Măgura 'Buduiasca'. 
Although grinding handstones and pestles have similar purposes and forms, their usage or function may be predicted based on a few characteristics. The size of the tools may indicate whether the tool was being used on a large or a small amount of material. The coarseness of the tools may also indicate how fine the resulting material had to be. Tools used to grind up sand or other materials for temper in the clay would likely be larger but not necessarily fine grained. Tools for grinding or crushing pigment might be smaller (since not as much material would be needed) but would need to be smoother. Of course, the tool would have to be harder than the material which it was breaking up. Pestles may be quartz, quartzite, chert or magmatic rock whereas mortars are often quartzite or sandstone.

Several artefacts which appear to be mortars were found at the study sites (see Figures 8). They may have been used for pigment grinding by rubbing against a small slab (Andreescu $e t$ al. 2008b; Mirea 2005a). Likewise, a handstone may have also been used to grind materials against a slab (Dal Sasso et al. 2014; Hamon 2008a; Šajnerová-Dušková et al. 2009). Chemical analysis may be able to detect traces of pigment on handstones (Domingo et al. 2012).

\section{Burnishing stones and smoothers}

Burnishing and smoothing are two very common methods of improving the appearance and functionality of ceramic vessels. Basically, smoothing helps in obtaining a more even surface of the ceramic objects by removing the rough parts and filling in the pits by using wet hand, cloth, grass, wool, pottery sherds, and others (Spaulding 1948; Valado 2008; Wayessa 2011; Zhushchikhovskaya \& Shubina 2006). They may be used to burnish entire surfaces or to produce decorative patterns before firing. They are usually produced from quartz, quartzite, or chert. As burnishing and smoothing tools from these sites are the focus of another paper, they will not be dealt with here in detail. Examples from Măgura 'Buduiasca' are show in Figure 9.

Viewing the artefacts at $16 \times$ magnification (or higher) through a stereomicroscope helped to indicate more about the type of usage (parallel or random scratches, crushed or pitted surfaces, and others), the intensity of use, and in some cases whether they were used against coarse or fine materials. Many of the polishing stones show parallel surface scratching consistent with the marks found on modern polishing stones (Crandell et al. 2012; Ionescu et al. 2015; Ionescu et al. 2012). (See Figure 10 for examples.)

There were many pottery fragments which had been ground flat or slightly curved on one edge. It is presumed that they were used to smooth pot surfaces before firing. Figure 11 shows examples from Măgura 'Buduiasca'. Vuković (2013) also provides examples of this type of tool. Figure 12 illustrates how they would have been used.

\section{Blades for decorating}

Blades knapped from chert are common at almost all Neolithic and Chalcolithic (for examples, see Figure 13). Among their varied purposes, some were likely also used to decorate pottery by incisions or by pressing designs into the surface of soft clay (see for example, Khalaily \& Kamaisky 2002). 
a
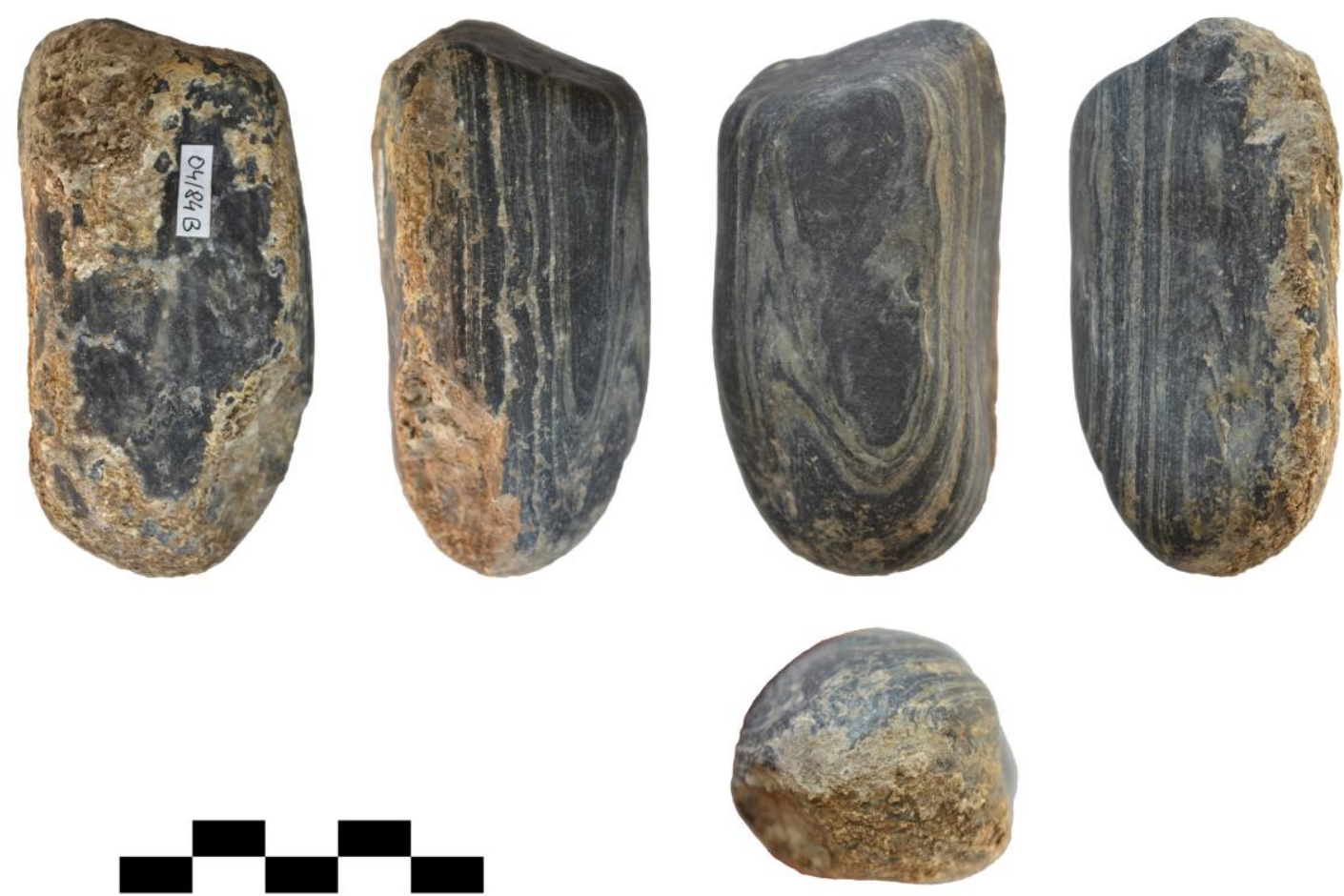

$15 \mathrm{~cm}-1$

b
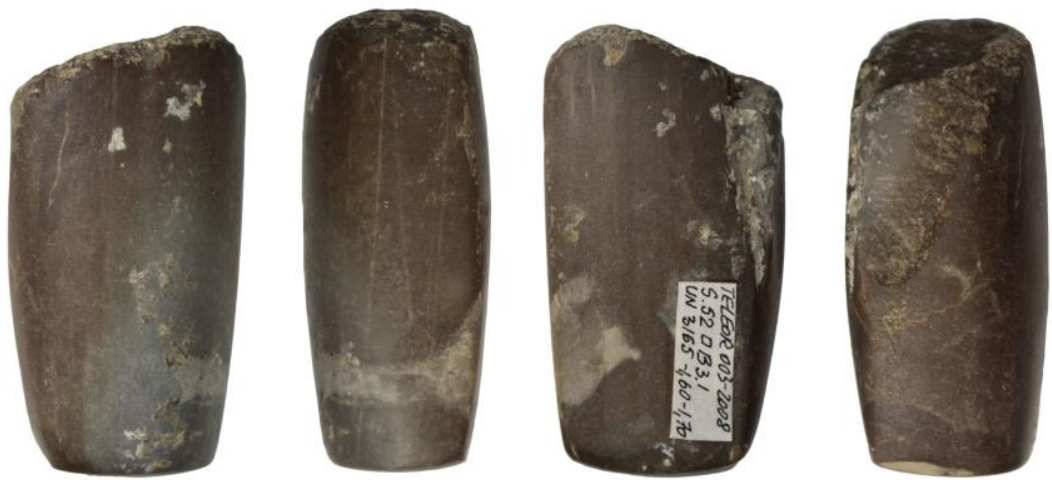

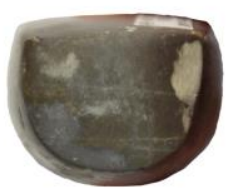

Figure 8. Examples of possible pestles from the Măgura 'Buduiasca' site. 

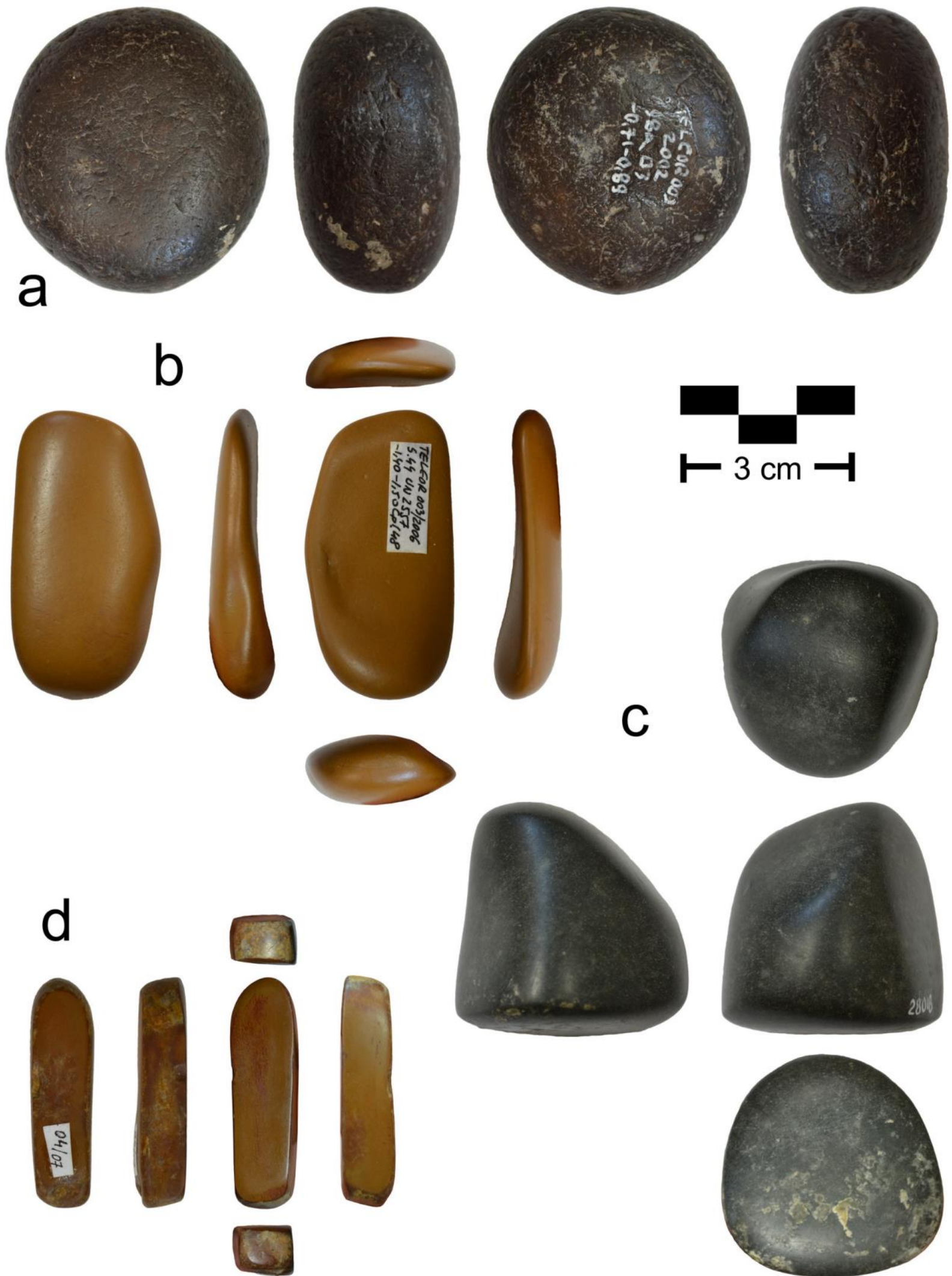

Figure 9. Examples of polishing stones. From a., b., d. Măgura 'Buduiasca'; c. Vităneşti 'Măgurice'. 


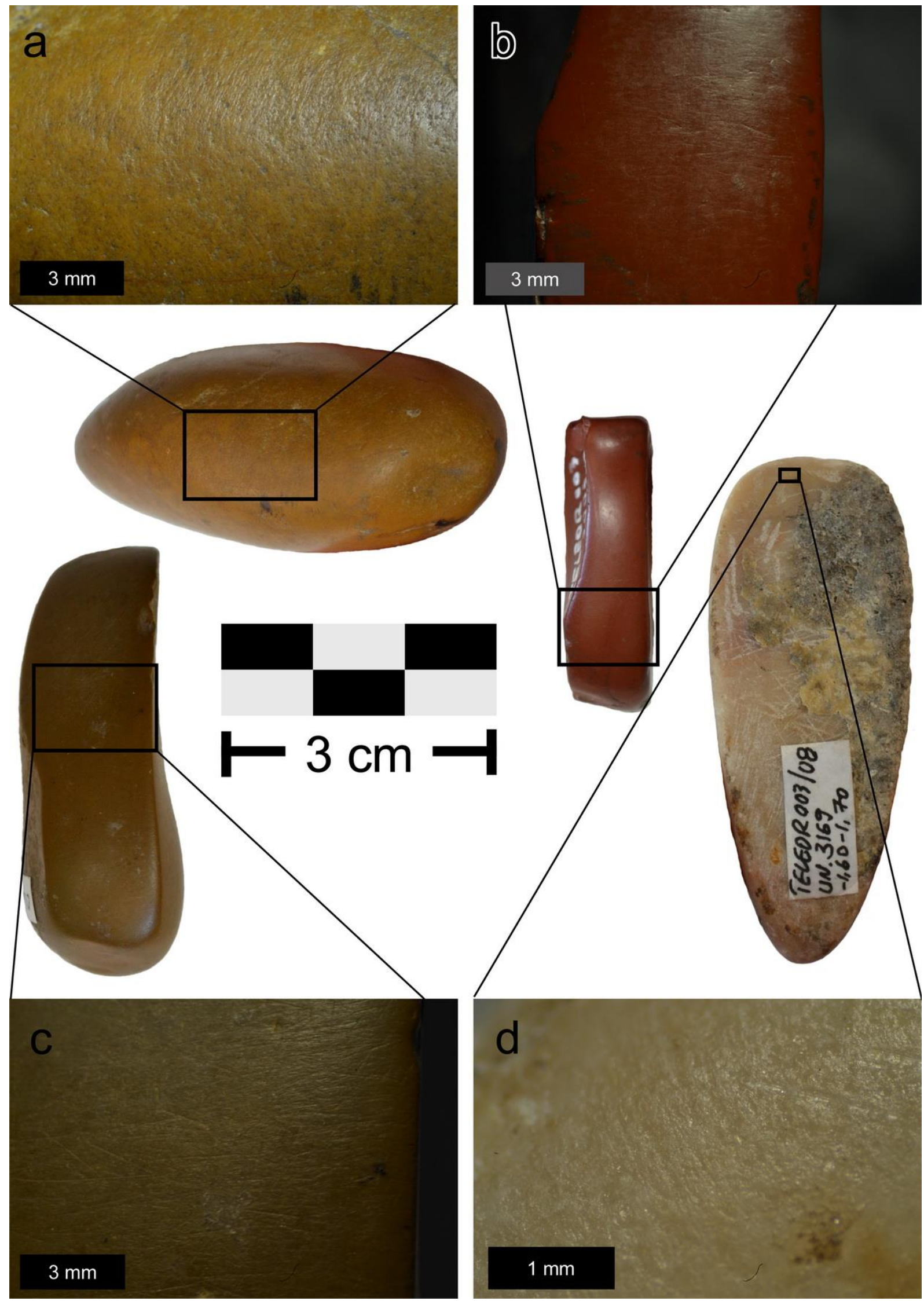

Figure 10. Parallel surface scratching consistent with the marks found on modern polishing stones. Examples from Măgura 'Buduiasca'. 

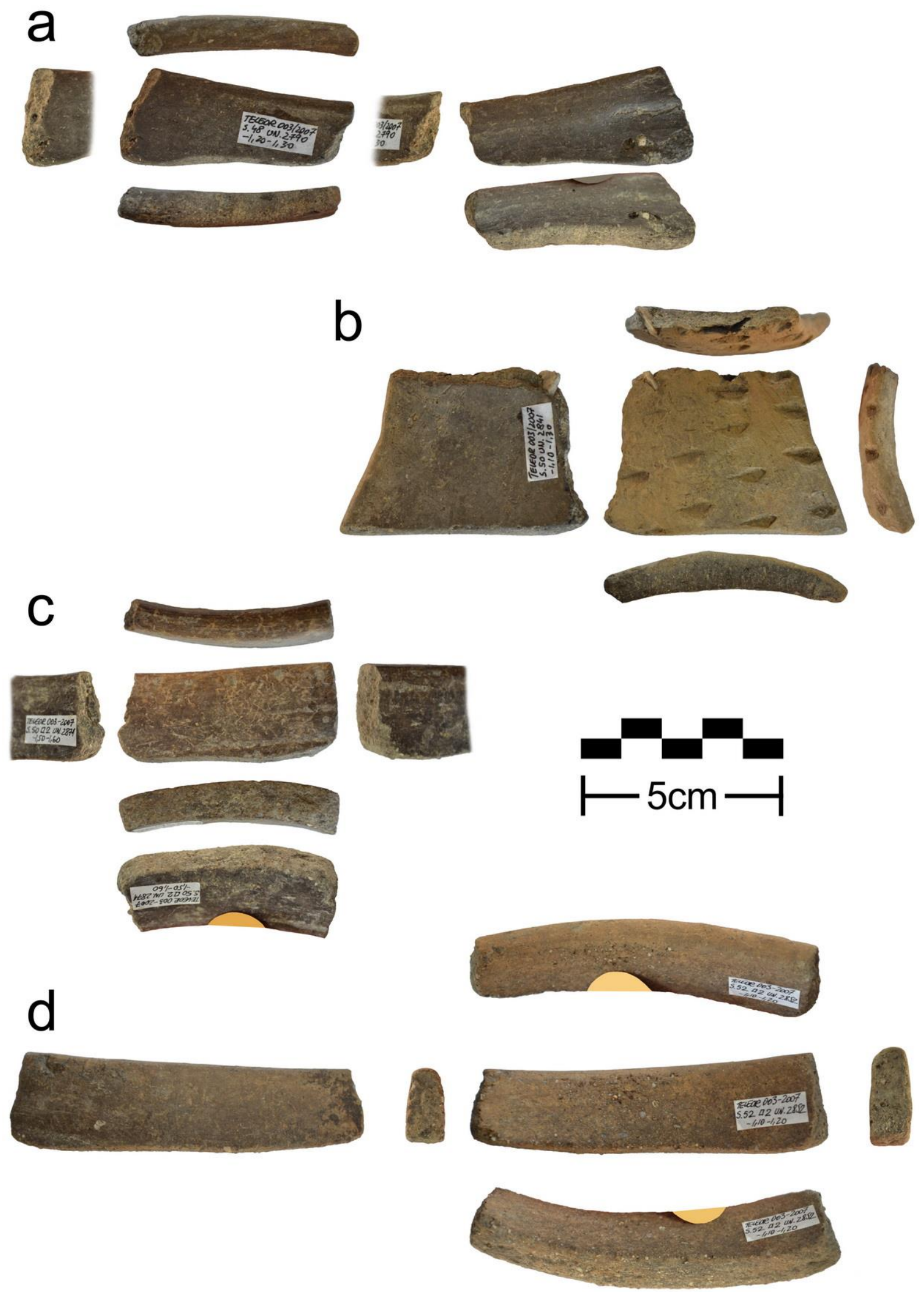

Figure 11. Examples of re-used ceramic sherd smoothers from Măgura 'Buduiasca'. 


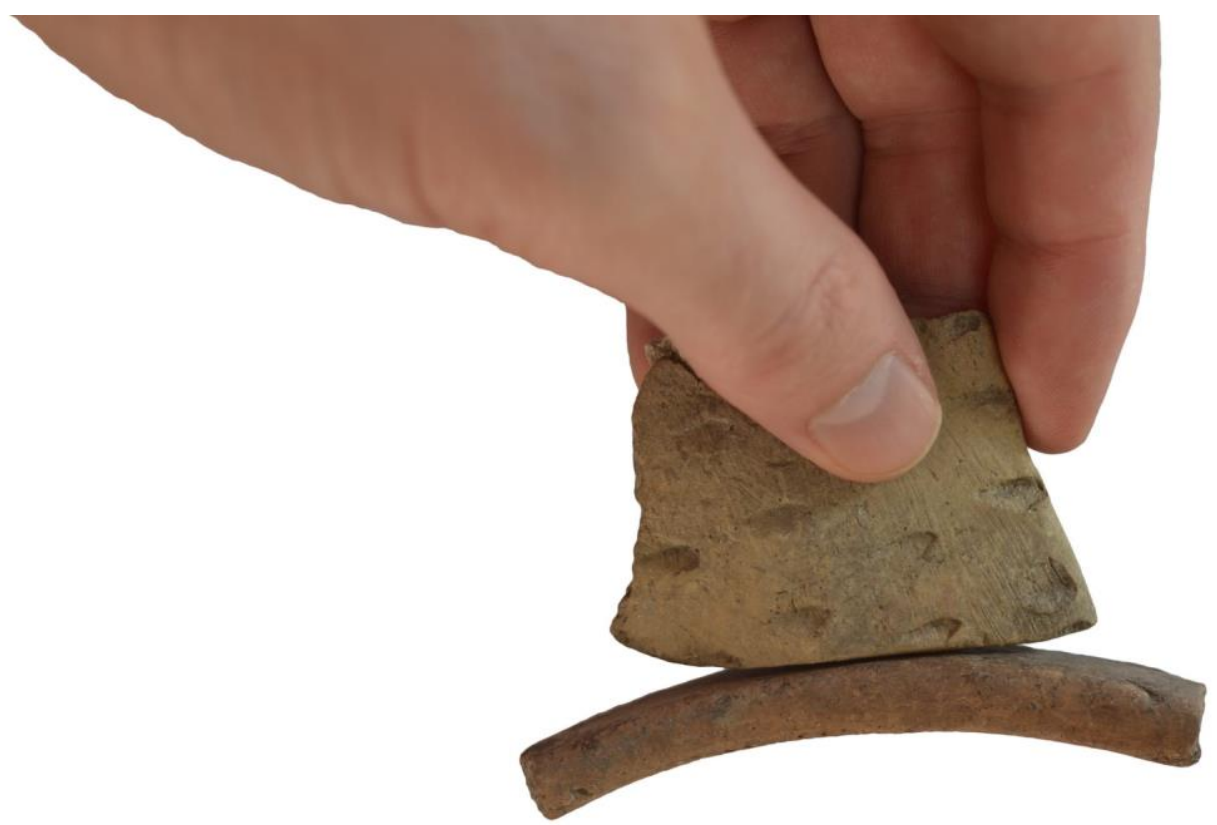

Figure 12. Illustration of how a re-used ceramic sherd smoother would be used.
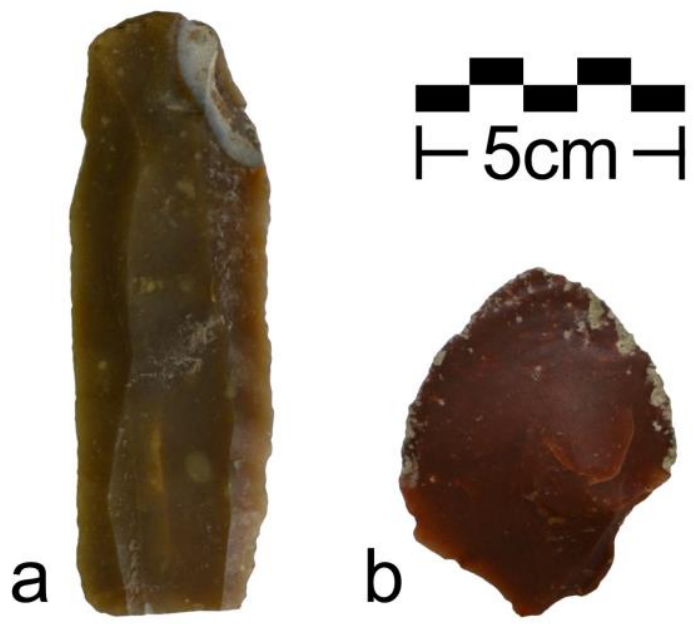

Figure 13. Examples of blades from Măgura 'Buduiasca'.

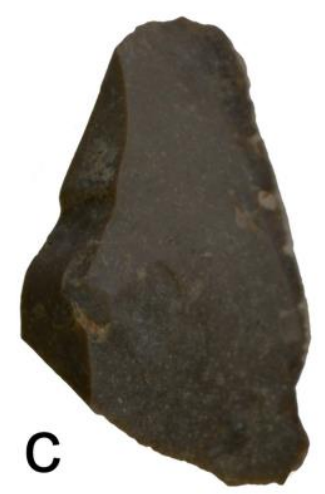

\section{Discussion}

There are possibly other uses but this paper focus on their potential involvement in the ceramics industry. This article is intended to help other researchers to identify possible tools. By knowing what to look for and what might be present within artefact assemblages, the function and usage of artefacts may be identified. It should be kept in mind that many of these tools likely had other more than one function. This paper simply focused on those which might have been involved in the ceramics production.

\section{Acknowledgements}

The study was financed by the PN-II-ID-PCE-2011-3-0881 project, granted to C.I. by the Romanian Ministry of Education and Research. C.I. also acknowledges subsidy by the Russian Government to support the "Program of competitive growth of Kazan Federal University among world class academic centers and universities". 


\section{References}

Andreescu, R.R. 2006, Proiectul „Începuturile civilizației europene. Neo-eneoliticul la Dunărea de Jo". In: Cronica cercetărilor arheologice din România. Campania 2005, CIMEC - Institutul de Memorie Culturală, Bucharest: p. 405-406. (in Romanian) ("The "Beginning of European Civilisation. Neo-Eneolithic on the Lower Danube" project") URL: http://www.cimec.ro/Arheologie/cronicaCA2006/Proiecte/proiectdunareadejos.ht $\mathrm{m}$

Andreescu, R.R. 2011, Dynamic of Neolithic habitation in Teleorman Valley, Southern Romania. In: The Lower Danube in Prehistory: Landscape Changes and HumanEnvironment Interactions (Mills, S. \& Mirea, P., Eds.), Publicaţiile Muzeului Judeţean Teleorman Vol. 3, Editura Renaissance, Bucharest: p. 15-30.

Andreescu, R.R. \& Bailey, D.W. 2002, Raport asupra săpăturilor arheologice de la Lăceni -

Valea Cioroaica, Măgura, Măgura - Bran, Măgura - Buduiască, și Vitănești. In: Cronica cercetărilor arheologice din România. Campania 2001, CIMEC - Institutul de Memorie Culturală, Bucharest: p. 195-199. (in Romanian) ("Report on the archaeological excavations at Lăceni - Valea Cioroaica, Măgura, Măgura - Bran, Măgura - Buduiască, and Vitănești”') URL: http://cronica.cimec.ro/detaliu.asp?k=1423

Andreescu, R.R. \& Bailey, D.W. 2004, Raport asupra sapaturilor arheologice de la Măgura Buduiasca, Teleor 003. In: Cronica cercetărilor arheologice din România. Campania 2003, CIMEC - Institutul de Memorie Culturală, Bucharest: p. 184-189. (in Romanian) ("Report on the archaeological excavations at Măgura - Buduiasca, Teleor 003") URL: http://cronica.cimec.ro/detaliu.asp?k=2285

Andreescu, R.R. \& Bailey, D.W. 2005, Raport asupra sapaturilor arheologice de la Măgura Buduiasca, Teleor 003. In: Cronica cercetărilor arheologice din România. Campania 2004, CIMEC - Institutul de Memorie Culturală, Bucharest: p. 224-234. (in Romanian) ("Report on the archaeological excavations at Măgura - Buduiasca, Teleor 003") URL: http://cronica.cimec.ro/detaliu.asp?k=3171

Andreescu, R.R. \& Bailey, D.W. 2006, Raport asupra sapaturilor arheologice de la Măgura Buduiasca, Teleor 003. In: Cronica cercetărilor arheologice din România. Campania 2005, CIMEC - Institutul de Memorie Culturală, Bucharest: p. 216-218. (in Romanian) ("Report on the archaeological excavations at Măgura - Buduiasca, Teleor 003") URL: http://cronica.cimec.ro/detaliu.asp?k=3436

Andreescu, R.R. \& Borțun, C. 1995, Raport asupra sapaturilor arheologice de la Vitănești Măgurice. In: Cronica cercetărilor arheologice din România. Campania 1994 CIMEC Institutul de Memorie Culturală, Bucharest. (in Romanian) ("Report on the archaeological excavations at Vitănești - Măgurice"); Accessed: 15 January 2016. URL: http://cronica.cimec.ro/detaliu.asp?k=136

Andreescu, R.R., Borțun, C. \& Mirea, C. 1996, Raport asupra sapaturilor arheologice de la Vitănești - Măgurice. In: Cronica cercetărilor arheologice din România. Campania 1995 CIMEC - Institutul de Memorie Culturală, Bucharest. (in Romanian) ("Report on the archaeological excavations at Vitănești - Măgurice"); Accessed: 15 January 2016. URL: http://cronica.cimec.ro/detaliu.asp?k=315 
Andreescu, R.R., Haită, C., Bălășescu, A., Radu, V., Mirea, P., Apope, Ș., Zaharia, P., Lazăr, C., Moldoveanu, K., Bailey, D.W., Mills, S., Thiessen, L. \& Stone, N. 2003, Raport asupra sapaturilor arheologice de la Măgura - Buduiasca, Teleor 003. In: Cronica cercetărilor arheologice din România. Campania 2002, CIMEC - Institutul de Memorie Culturală, Bucharest: p. 189-190. (in Romanian) ("Report on the archaeological excavations at Măgura - Buduiasca, Teleor 003”)

URL: http://cronica.cimec.ro/detaliu.asp?k=2015

Andreescu, R.R., Mirea, P. \& Apope, Ș. 2001, Dinamica locuirii neo-eneolitice pe Valea Teleormanului. Cultura și Civilizație La Dunărea de Jos, 16-17: 29-34. (in Romanian) ("The dynamic of Neo-Eneolithic dwellings in the Teleorman Valley")

Andreescu, R.R., Mirea, P., Moldoveanu, K. \& Torcică, I. 2009a, Noi descoperiri în așezarea Gumelnițeană de la Vitănești 'Măgurice'. Buletinul Muzeului Județean Teleorman, 1: 75-92. (in Romanian) ("New discoveries in the Gumelnița settlement at Vitănești 'Măgurice'“)

Andreescu, R.R., Mirea, P., Pompilia, Z., Bălășescu, A., Radu, V., Haită, C., Bailey, D.W., Mills, S., Thissen, L., van As, A. \& Jacobs, L. 2007, Raport asupra sapaturilor arheologice de la Măgura - Buduiasca - Boldul lui Moș Ivănuș. In: Cronica cercetărilor arheologice din România. Campania 2006, CIMEC - Institutul de Memorie Culturală, Bucharest: p. 226-228. (in Romanian) ("Report on the archaeological excavations at Măgura - Buduiasca - Boldul lui Moș Ivănuș”)

URL: http://cronica.cimec.ro/detail.asp?k=3706

Andreescu, R.R., Mirea, P., Pompilia, Z., Torcică, I., Dumitru, M., Nica, T., Bălășescu, A., Radu, V., Haită, C. \& Beldiman, C. 2009b, Raport asupra sapaturilor arheologice de la Măgura - Buduiasca - Boldul lui Moș Ivănuș. In: Cronica cercetărilor arheologice din România. Campania 2008, CIMEC - Institutul de Memorie Culturală, Bucharest: p. 144-146. (in Romanian) ("Report on the archaeological excavations at Măgura Buduiasca - Boldul lui Moș Ivănuş”) URL: http://cronica.cimec.ro/detail.asp?k=4040

Andreescu, R.R., Mirea, P., Torcică, I., Pompilia, Z. \& Dumitru, M. 2008a, Raport asupra sapaturilor arheologice de la Măgura - Buduiasca - Boldul lui Moș Ivănuș. In: Cronica cercetărilor arheologice din România. Campania 2007, CIMEC - Institutul de Memorie Culturală, Bucharest: p. 195-198. (in Romanian) ("Report on the archaeological excavations at Măgura - Buduiasca - Boldul lui Moș Ivănuş”)

URL: http://cronica.cimec.ro/detail.asp?k=3923

Andreescu, R.R., Moldoveanu, K., Olariu, C., Bălășescu, A., Radu, V., Haită, C., Mirea, P., Torcică, I., Zaharia, P. \& Dumitru, M. 2008b, Raport asupra sapaturilor arheologice de la Vitănești - Măgurice. In: Cronica cercetărilor arheologice din România. Campania 2007, CIMEC - Institutul de Memorie Culturală, Bucharest: p. 327-328. (in Romanian) ("Report on the archaeological excavations at Vitănești - Măgurice") URL: http://cronica.cimec.ro/detaliu.asp?k=3800

Bassetti, M. \& Zamboni, S. 1997, The unpolished lithic industry of Isera La Torretta (TN). Preistoria Alpina, 33: 97-99.

Crandell, O.N. 2013, The provenance of Neolithic and Chalcolithic stone tools from sites in Teleorman county, Romania. Buletinul Muzeului Județean Teleorman, Seria Arheologie, 5: 1-19.

URL: http://www.muzeulteleorman.ro/files/03_BMJT5_Crandell.pdf 
Crandell, O.N., Ionescu, C. \& Hoeck, V. 2012, Macroscopic and microscopic aspects of polishing ceramic pots using water worn pebbles. In: 39th International Symposium on Archaeometry: Programme and Abstracts (Braekmans, D., Honings, J. \& Degryse, P., Eds.), Centre for Archaeological Sciences, KU Leuven, Leuven: p. 344.

Domingo, I., García-Borja, P. \& Roldán, C. 2012, Identification, processing and use of red pigments (hematite and cinnabar) in the Valencian Early Neolithic (Spain). Archaeometry, 54(5): 868-892. doi:10.1111/j.1475-4754.2011.00650.x

Hamon, C. 2008a, From Neolithic to Chalcolithic in the Southern Caucasus: Economy and macrolithic implements from Shulaveri-Shomu sites of Kwemo-Kartli (Georgia). Paléorient, 34(2): 85-135. doi:10.3406/paleo.2008.5258

Hamon, C. 2008b, Functional analysis of stone grinding and polishing tools from the earliest Neolithic of north-western Europe. Journal of Archaeological Science, 35(6): 15021520. doi:10.1016/j.jas.2007.10.017

Ionescu, C., Hoeck, V., Crandell, O.N. \& Šarić, K. 2015, Burnishing versus smoothing in ceramic surface finishing: A SEM study. Archaeometry, 57(1): 18-26. doi:10.1111/arcm.12089

Ionescu, C., Hoeck, V. \& Simon, V. 2012, The "Black Ceramics of Marginea" (Romania): A modern analogue of ancient ceramics? Acta Mineralogica-Petrographica, Abstract Series, 7: 65.

Khalaily, H. \& Kamaisky, E. 2002, The use of sickle blades for decorating pottery in the Wadi Rabah culture: The case of Tel Dover. In: In Quest of Ancient Settlements and Landscapes: Archaeological Studies in Honour of Ram Gophna. Tel Aviv (van den Brink, E.C.M. \& Yannai, E., Eds.), Ramot Publishing, Tel Aviv: p. 57-64.

Kozlowski, S.K. 1989, Nemrik 9, a PPN Neolithic site in Northern Iraq. Paléorient, 15(1): 25-31. doi:10.3406/paleo.1989.4482

Mărgărit, M., Bălăşescu, A. \& Mirea, P. 2014, Prelucrarea oaselor de ovis aries/capra hircus în nivelul Starčevo - Criş I din aşezarea de la Măgura 'Buduiasca' ('Boldul lui Moş Ivănuş’). Buletinul Muzeului Județean Teleorman. Seria Arheologie, 6: 7-18. (in Romanian) ("Processing of Ovis Aries/Capra Hircus bones from the Starčevo-Criş I level at Măgura 'Buduiasca' ('Boldul lui Moş Ivănuş') settlement”) URL: http://www.muzeulteleorman.ro/files/01\%20MARGARIT-BALASESCUMIREA_\%20BMJT\%206_C.pdf

Mirea, P. 2005a, Considerații asupra locuirii Dudești din sud-vestul Munteniei. Studii de Preistorie, 2: 75-92. (in Romanian) (“Considerations regarding Dudești dwellings of south-west Muntenia")

Mirea, P. 2005b, Considerații asupra locuirii Starčevo-Criș din sud-vestul Munteniei. Cultura și Civilizație La Dunărea de Jos, 22: 37-52. (in Romanian) (“Considerations regarding Starčevo-Criș dwellings of south-west Muntenia")

Mirea, P. 2009, On Vădastra habitation in southern Romania: Context and results from the Teleorman Valley. In: Itenaria in praehistorica. Studia In honorem magistri Nicolae Ursulescu (Cotiugă, V., Tencariu, F.A. \& Bodi, G., Eds.), Editura Universităţii “Al. I. Cuza", Iaşi: p. 281-293.

Mithen, S., Finlayson, B. \& Shaffrey, R. 2005, Sexual symbolism in the Early Neolithic of the Southern Levant: Pestles and mortars from WF16. Documenta Praehistorica, 32: 103110. doi:10.4312/dp.32.6 
Nadel, D. \& Rosenberg, D. 2010, New insights into Late Natufian bed rock features (mortars and cupmarks). Eurasian Prehistory, 7(1): 61-83.

Özkaya, V. 2009, Excavations at Körtik Tepe. A new Pre-Pottery Neolithic A site in southeastern Anatolia. Neo-Lithics, 2(09): 3-8.

Rosenberg, D. \& Gopher, A. 2010, Food processing tools and other groundstone implements from Gilgal I and Gilgal III. Chapter 9. In: Gilgal: Early Neolithic Occupations in the Lower Jordan Valley. The Excavations of Tamar Noy (Bar-Yosef, O., Goring-Morris, A.N. \& Gopher, A., Eds.), Oxbow Books, Oxford: p. 139-175.

Šajnerová-Dušková, A., Fridrich, J. \& Fridrichová-Sýkorová, I. 2009, Pitted and grinding stones from Middle Palaeolithic settlements in Bohemia: A functional study. In: Nonflint Raw Material Use in Prehistory: Old Prejudices and New Directions. Proceedings of the XV Congress of the UISPP (Sternke, F., Eigeland, L. \& Costa, L.-J., Eds.), BAR Vol. S1939, Archaeopress, Oxford: p. 145-152.

Dal Sasso, G., Maritan, L., Salvatori, S., Mazzoli, C. \& Artioli, G. 2014, Discriminating pottery production by image analysis: A case study of Mesolithic and Neolithic pottery from Al Khiday (Khartoum, Sudan). Journal of Archaeological Science, 46: 125-143. doi:10.1016/j.jas.2014.03.004

Simmons, A.H. \& Rollefson, G.O. 1984, Neolithic 'Ain Ghazal (Jordan): Interim report on the first two seasons, 1982-1983. Journal of Field Archaeology, 11(4): 387-395. doi:10.1179/jfa.1984.11.4.387

Spaulding, A.C. 1948, Committee on nomenclature pottery (continued). Plains Archeological Conference News Letter, 1(4): 73-82. URL: http://www.jstor.org/stable/25664694

Valado, M.T. 2008, Identifying lightly used polishing stones: Experiments and implications. In: New Approaches to Old Stones: Recent Studies of Ground Stone Artifacts (Rowan, Y.M. \& Ebeling, J.R., Eds.), Equinox Publishing, London: p. 173-181.

Vuković, J. 2013, Фрагменти грнчарије као алатке у каснонеолитској Винчи. Starinar, 63: 191-207. (in Serbian) ("Pottery shreds as tools in late Neolithic Vinca") doi:10.2298/sta1363191v

Wayessa, B.S. 2011, The technical style of Wallaga pottery making: An ethnoarchaeological study of Oromo potters in southwest highland Ethiopia. African Archaeological Review, 28(4): 301-326. (in English) doi:10.1007/s10437-011-9103-7

Wright, K. 1992, A classification system for ground stone tools from the prehistoric Levant. Paléorient, 18(2): 53-81. doi:10.3406/paleo.1992.4573

Wright, K.I. 1994, Ground-stone tools and hunter-gatherer subsistence in southwest Asia: Implications for the transition to farming. American Antiquity, 59(2): 238-263. doi:10.2307/281929

Zhushchikhovskaya, I.S. \& Shubina, O.A. 2006, Pottery making and the culture history of Neolithic Sakhalin. In: Archaeology in Northeast Asia: On the pathway to Bering Strait (Dumond, D.E. \& Bland, R.L., Eds.), University of Oregon Anthropological Papers Vol. 65, Museum of Natural and Cultural History and Dept. of Anthropology, University of Oregon, Eugene, Oregon: p. 91-128. 
Zurro, D., Risch, R. \& Clemente Conte, I. 2005, Analysis of an archaeological grinding tool: What to do with archaeological artefacts? In: L'outillage lithique en contextes ethnoarchéologiques (Lithic toolkits in ethnoarchaeological contexts) (Terradas, X., Ed.), BAR International Series Vol. 1370, Archaeopress, Oxford: p. 57-64. 